\title{
Has China Displaced the Outward Investments of OECD Countries?
}

\author{
Shujie Yao and Pan Wang*
}

\begin{abstract}
As China has rapidly emerged as one of the world's largest investors abroad, there has been a hectic debate in the literature on whether its emergence as a major foreign investor may have undermined the importance of western industrialised economies, including those in the Organisation for Economic Cooperation and Development (OECD). This paper aims to investigate whether this is the case. The study uses a panel dataset covering 155 countries, including 33 in the OECD, where China had invested during 2003-09. This is by far the most comprehensive dataset of China's outward foreign direct investment (OFDI). A two-stage least squared (TSLS) regression approach is adopted for our econometric models according to an established augmented gravity model in the literature. The empirical results show clear evidence that China's OFDI displaces that of the OECD countries, but the argument that China's emergence is a 'new colonialism' is not supported as OECD countries' OFDI in resource abundant host countries, particularly that in Africa and Latin America, does not appear to have been displaced by China's OFDI.
\end{abstract}

Key words: outward FDI, displacement effect, China, OECD

JEL: F21, O57

\footnotetext{
* Shujie Yao is professor of economics and Chinese sustainable development, head of the School of Contemporary Chinese Studies, University of Nottingham; and special chair professor of economics, Xi'an Jiaotong University, China. Pan Wang is a sales executive at the Industrial and Commercial Bank of China.
} 


\section{Introduction}

China's outward foreign direct investments (OFDI) have grown exponentially over recent years (Figure 1). The United Nations Conference on Trade and Development (UNCTAD) has reported that China will become the second largest FDI source country after the US before 2015 .

In 2010, China accounted for $5.1 \%$ of global FDI flows. It was ranked the $5^{\text {th }}$ largest foreign investor in the world and the largest among all the developing countries (MOFCOM, 2010). In that year, China's total outward investments amounted to $\$ 69$ billion, accumulating total stock to $\$ 317$ billion.

Figure 1: China’s OFDI flow and stock values 1991-2010 (\$ billion)



Sources: Data for 1991-2002 are obtained from UNCTAD, World Investment Reports (various issues). Data for 2003-2010 are obtained from MOFCOM (2011), Statistical Bulletin of China's Outward Foreign Direct Investment.

China's rapid emergence as a major investor abroad has triggered increasing anxiety in the world (The Economist, 2008). In fact, China's overseas investments may have a widespread impact on both host and home countries of FDI. 
However, some FDI host countries have expressed concern over the expansion of China's investments, made largely by its state-owned enterprises (SOEs) whose investment motivation may have a political component.

As for the recipient countries of FDI, Chinese capital may well lead to displacement of their investments and intensify competition (The Economist, 2010). Rosen and Hanemann (2009) explicitly point out that China is capable of challenging the existing foreign investment pattern, resulting in a powerful impact on international politics and foreign relations. China's Western rivals fear being crowded out of foreign markets because Chinese firms are backed by the government with low-cost credits and soft budget constraints seemingly without limits (Yao, et al., 2010).

As the world's dominant FDI source countries, members of the Organisation for Economic Cooperation and Development (OECD) may be the most affected by China's rapid rise as a business superpower. ${ }^{1}$ Outward investments by OECD countries grew at less than a quarter of China's rate during the period 2003-2009.

The key research question in this paper is whether China's OFDI has had any displacement effect on that of other countries, especially those in the OECD. A preliminary examination of Figure 2 may show such evidence. The OFDI share of OECD countries in the global total decreased alongside an increase in China's share.

\footnotetext{
${ }^{1}$ To illustrate the effect of China's OFDI on the world, the OECD countries are selected for two reasons. First, the OECD has a rich dataset covering many bilateral investment flows between its member states and other countries, including China for a long period of time. Second, the OECD countries had an average share of 84\% of the global OFDI during 2003-2009.
} 
Figure 2: The share of OECD countries and China in world OFDI



Sources: China's data are obtained from MOFCOM (2009). OECD country data are obtained from UNCTAD, World Investments Report (various issues).

Whether this evidence is statistically significant requires much more careful econometric analysis, which is the main objective of this paper. In addition, the empirical models will help in identifying the key determinants of China's OFDI and to differentiate its impact on the different kinds of host and home countries of foreign investments.

Existing studies on China's OFDI have mainly focused on locational determinants with limited data availability and over a relatively short period of time (Buckley et al., 2008; Cheung and Qian, 2009). In terms of research methodology, Greenaway et al. (2008) find evidence of China's exports having a displacement effect on those of other Asian countries.

Following Greenaway et al. (2008), a panel dataset covering 155 countries, including 33 in the OECD where China invested over 2003-09, is used to construct a gravity 
model to achieve the research objectives outlined above. A two-stage least squared (TSLS) estimation approach is adopted to overcome the endogeneity problem that may be encountered by the Ordinary Least Squared (OLS) method.

The empirical results show that China's OFDI does displace that of the OECD countries in a third country in general, but the finding depends on the validity of the instrumental variable (IV). This negative causal effect implies that a $10 \%$ rise in China's OFDI leads to a more than 3\% decrease in the OFDI of the OECD countries.

Some sensitivity analysis and robustness tests are also carried out to investigate whether and how the displacement effects may vary in different kinds of host and home countries of FDI.

It is interesting to find that contrary to the often-heard 'new colonialism' argument, China's OFDI does not displace the OFDI of the OECD countries in oil and minerals (e.g., iron ores) abundant host countries or in Africa and Latin America. In contrast, the displacement effect in host countries that are less abundant in oil and minerals or located in Asia, Europe and North America is significant and positive.

This paper is organised as follows. Section 2 reviews the development of China's OFDI. Section 3 introduces the basic model and discusses the data and regression techniques. Section 4 presents the regression results and their implications. Section 5 carries out some robustness checks on the basic model. The final section concludes and discusses policy implications. 


\section{Background of China's OFDI}

China has achieved great economic success since 1978. Its annual average growth rate of gross domestic product (GDP) was 9.9\% during the period 1978-2009. By 2010, China overtook Japan as the world's second largest economy and is now set to surpass the US to be the largest before 2025 .

Meanwhile, China's foreign exchange reserves have increased rapidly, amounting to \$3.2 trillion by 2011 (Figure 3).

Figure 3: China's GDP and foreign exchange reserves (US\$, bil)

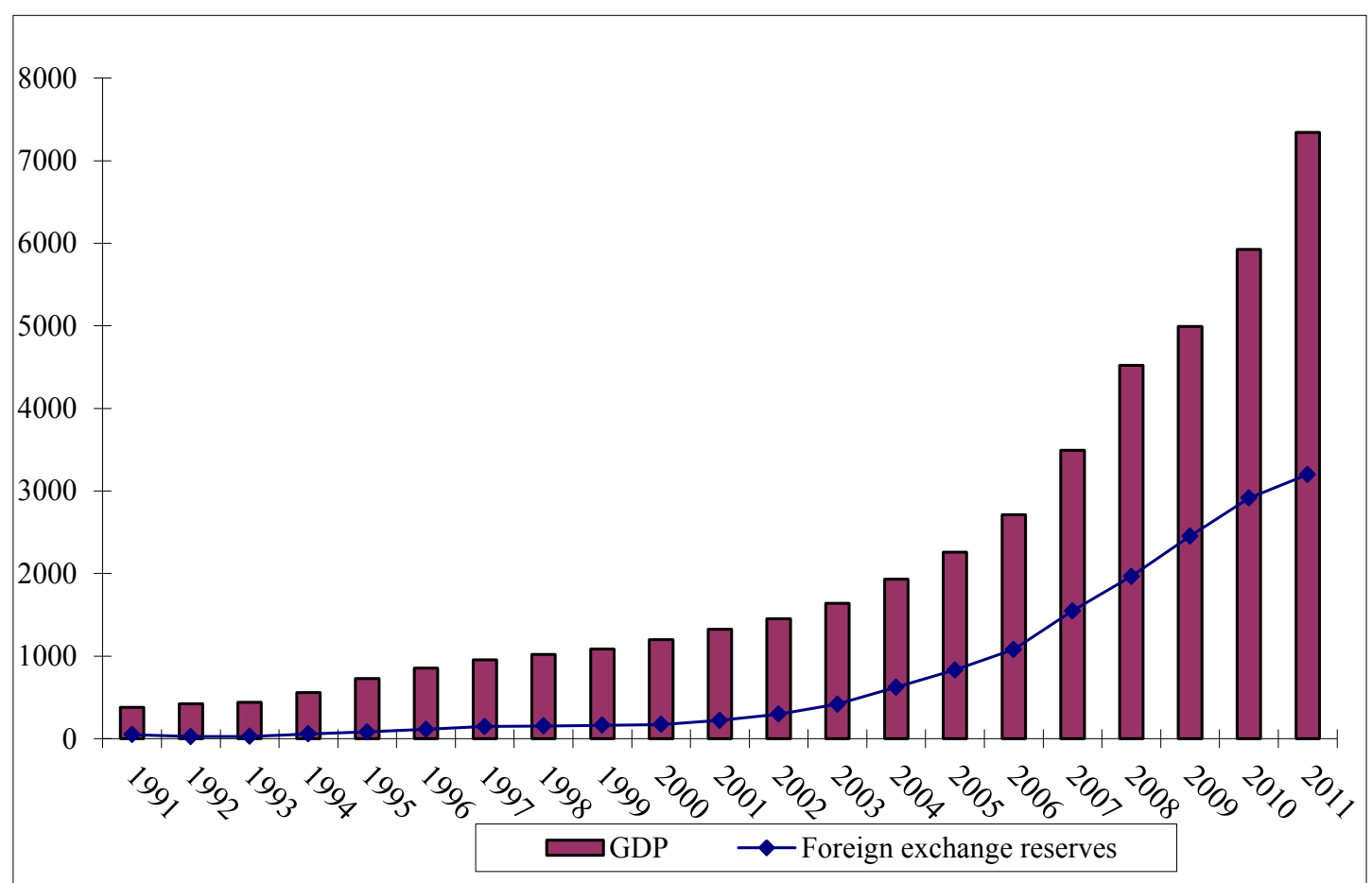

Data Source: World Bank's World Development Indicators (various years).

Fast economic development has raised China's desire for advanced technology. The acquisition of IBM's PC business is a stunning example, followed by the acquisition of Rover by Nanjing Auto and the acquisition of Volvo by Geely Auto. China's foreign investments have also been extended to securing the supply of oil and other 
resources from Australia, Africa, Latin America, the Middle East, Russia and Central Asia.

Although China is emerging as a significant source of OFDI, the development of its OFDI has a short history. In the initial stage, China's OFDI was mainly motivated by political rather than economic incentives (Cheung and Qian, 2009; Voss et al., 2008). OFDI activities were promoted by both central and local administrations after Deng Xiaoping's South Tour in 1992. The launch of the 'Go Global' policy in 2002 and China's accession to the WTO in 2001 boosted overseas investments. The OFDI policy was further liberalised from an approval regime to a supervision and assistance regime by the Ministry of Commerce (MOFCOM). ${ }^{2}$

The annual average growth rate of China's OFDI was 71\% during 2003-09, four times as high as the world average. ${ }^{3}$ Yao and Sutherland (2009) and Xiao and Sun (2005) point out that the rapid expansion of China's OFDI was due to state policy to substantially subsidise state-owned enterprises (SOEs) through cheap credits and softbudget constraints to secure a long-term and stable supply of natural resources.

China's rising importance as a foreign investor has been interpreted as a threat rather than an opportunity to other countries in the West. The Economist (2008), for instance, claims that Chinese investments are undermining the West's existing interests, and that China is stealing natural resources and colonising Africa.

\footnotetext{
${ }^{2}$ MOFCOM was established from the former the Ministry of Foreign Trade and Economic Cooperation (MOFTEC) in 2003.

${ }^{3}$ The growth rates are calculated by the authors. Data of China's OFDI are obtained from MOFCOM (2009). Data of the world's OFDI are obtained from UNCTAD World Investment Report (various issues).
} 
The following sections will answer the following questions: what are the consequences of China's OFDI on the world economy? To what extent has China's OFDI displaced that of the OECD countries?

\section{Methodology and models}

To examine the impact of China's OFDI on the OFDI of OECD countries in a given host country, the basic gravity model includes the OFDI of OECD countries as the dependent variable and China's OFDI as the main explanatory variable along with a set of control variables.

The gravity model performs like a workhorse model for many empirical studies on bilateral economic relations, accounting for resistance and friction factors such as distance and language. This kind of model has been criticised for lacking a strong theoretical foundation ever since Tinbergen's (1962) first application to an international trade study, even though it has strong explanatory power in empirical studies.

Most studies have specified the gravity model intuitively, without formal identifications. Following Anderson (1979), an increasing number of studies have sought to explain the success of the gravity model (Bergstrand, 1985, 1989; Evenett and Keller, 2002; Deardorff, 1995; Helpman, 1987; Hummels and Levisohn, 1995).

The gravity model has been applied in the study of the behaviour of China's OFDI in Buckley et al. (2008), and Cheung and Qian (2009). Our benchmark gravity-type 
specification is given in Equation (1), where $\beta_{1}$ represents the impact of China's OFDI on the OFDI of OECD countries in a given host country. A negative value of $\beta_{1}$ represents a displacement effect, meaning that the OFDI of OECD countries declines following a rise in China's OFDI.

$$
\begin{aligned}
& \ln O_{E C D O F D I F}=\beta_{1} \ln C O F D I F_{i t}+\beta_{2} \ln R G D P_{i t}+\beta_{3} \ln R G D P P C_{i t} \\
& +\beta_{4} \text { Techno } \log y_{i t}+\beta_{5} \operatorname{Re} \text { sources }_{i t}+\beta_{6} \ln R G D P_{j t} \\
& +\beta_{7} \ln \text { RGDPPC }_{j t}+\beta_{8} \text { Techno log } y_{j t}+\beta_{9} \operatorname{Re}_{\text {sources }} \text { tt } \\
& +\beta_{10} \ln \text { Exch }_{j i t}+\beta_{11} \ln \text { Area }_{j i}+\beta_{12} \text { Colony }_{j i}+\beta_{13} \text { Comcol }_{j i} \\
& +\beta_{14} \text { ComLag }_{j i}+\beta_{15} \text { Contig }_{j i}+\beta_{16} \ln \text { Dist }_{j i}+\beta_{17} \text { Smctry }_{j i} \\
& +\beta_{18} \text { Trend }+\eta_{j}+\varepsilon_{j i t}
\end{aligned}
$$

In equation (1), $j$ denotes a home (OECD) country, $i$ a host country, and $t$ year. $O E C D F D I F_{j i t}$ is FDI flow from $j$ to $i$ in $t$. COFDIF it is FDI flow from China to $i$ in $t$. $R G D P$ and $R G D P P C$ are respectively real GDP and real GDP per capita. Technology means the technology level of $i$ or $j$. Resources refers to whether $i$ or $j$ are resource rich. Exch is the bilateral real exchange rate. Area is the product of land areas of $j$ and $i$. Colony takes 1 if $i$ and $j$ used to have a colonial relation and 0 otherwise. Comcol takes 1 if $j$ and $i$ were ever colonised by the same country and 0 otherwise. ComLag takes 1 if $j$ and $i$ share the same language and 0 otherwise. Contig takes 1 if $j$ and $i$ are contiguous and 0 otherwise. Disc is distance between $j$ and $i$. Smctry takes 1 if $j$ and $i$ were ever the same country and 0 otherwise. $\varepsilon_{j i t}$ is an error term.

Real GDP is a proxy measure of market size. According to Dunning (1993, 1998), a larger GDP implies a bigger market and more business opportunities in a host country. An increase in a home country's GDP implies a greater capability to invest abroad. 
Following Braconier et al. (2002), the GDPs of both host and home countries are included in the model to distinguish their different characteristics.

GDP per capita represents the level of economic development (Lipsey, 1999; Lane, 2000; Dunning, 1981, 1995; Dunning et al., 2001). As a result, real GDP per capita of both home and host countries are included in the model to capture the market effects.

China's OFDI has a clear motivation in seeking foreign technologies and brands (Child and Rodrigues, 2005; Mock et al., 2008). According to the OECD (2008), China also uses its technology as an advantage to invest in many African and other less developed countries.

Many empirical studies (Driffield and Love, 2003; Fosfuri and Motta, 1999; Siotis, 1999) have demonstrated that technology-seeking, or technology-exporting are two relevant motivations when investment decisions are made for both host and home countries. This is why our basic model includes variables representing the technology levels of both host and home countries.

The basic model also includes variables that represent the level of resource endowments of both types of countries as these are considered important in some empirical studies (Zhan, 1995; Ye, 1992; Taylor, 2007).

Gastanaga et al. (1998) and Noorbakhsh et al. (2001) emphasise the importance of natural resources in FDI analysis, as resource abundance can be a country-specific 
advantage in attracting FDI (Dunning, 1993, 1998; Asiedu, 2006; Cheng and Ma, 2007; Park, 2003).

Following Cheung and Qian (2009) and Zhang (2009), the share of fuels, ores and metal exports in merchandise exports is used to represent the resource abundance of a host country. ${ }^{4}$

The bilateral real exchange rates of OECD countries are included to control the hosthome country bilateral effect. The bilateral exchange rate is an important determinant of OFDI (Froot and Stein, 1991). Froot and Stein (1991) argue that internal financing is cheaper than external financing in an imperfect capital market, and the appreciation of home currency strengthens overseas activities. Goldberg and Klein (1998) indicate that depreciation of host country currency would attract more investment, because operation costs are lower and capital return higher.

Other researchers argue that appreciation of home country currency may reduce OFDI. Cushman (1985) and Summary and Summary (1995) argue that if a home country's subsidiaries need to import intermediate goods from the home country, currency appreciation in the home country would make imports more expensive and thus reduce OFDI. Goldberg and Klein (1998) also indicate that the depreciation of a home country's currency increases OFDI along the lines of a similar argument.

A wide range of variables are used to measure host-home country bilateral economic friction, including distance, colonial relation, common languages and so on.

\footnotetext{
${ }^{4}$ Kolstad and Wiig (2009) illustrated the reasons why natural resources export share was a better proxy than natural resources endowments.
} 
Standard panel estimations rest on a strong assumption of exogeneity and estimations are unbiased only if explanatory variables are exogenous. This assumption is challenged if the explanatory variables are not exogenous.

In this study, unobserved determinants left in the error term may simultaneously affect the OFDI of the OECD countries and China's OFDI in a third country. This means that OLS estimations may be spurious due to an omitted variable bias.

To correct this endogeneity bias, an instrumental variable (IV) estimation approach, or a two stage least squared (TSLS) method, is adopted in the regressions. In the first stage, exogenous IVs are included to estimate the predicted value of an endogenous variable, namely, China's OFDI in the host country. The standard TSLS technique includes not only the IVs but also all explanatory variables in the first stage regression.

The predicted value of China's OFDI is included in the second stage regression to obtain consistent estimators. The IV estimator is less efficient than a conventional estimator and the TSLS estimation is redundant if the suspicious independent variable is in fact exogenous. Therefore, an endogeneity test should be conducted first before the TSLS method is applied.

\section{Selection of IVs}

The precision of TSLS estimation lies in the appropriateness of IVs. An appropriate IV should not only be econometrically valid but also economically justifiable. The 
question here remains whether the causal effect of China's OFDI on OECD's OFDI, after controlling for a heterogeneity bias, connects to the relation between China's OFDI and IVs.

Following Greenaway et al. (2008), the logarithm of China's distance to a third country (lnChinaDist ${ }_{i}$ ) is selected as the first IV. The logarithm of China's bilateral real exchange rate with a third country $\left(\operatorname{lnChinaExch} h_{i t}\right)$ is selected as the second IV to instrument China's OFDI. The advantage of selecting $\operatorname{lnChinaExch}_{i t}$ as an IV is that its value changes with the host country as well as with time, unlike Greenaway et al. (2008) and Eichengreen et al. (2007), who select China's GDP, which only changes with time.

First IV: China's distance to a third country (lnChinaDist)

The relationship between China's OFDI in a host country and its distance from China could be negative or positive. Buckley and Casson (1981) illustrate that OFDI increases with distance. In contrast, Zhang (2009) and Buckley et al. (2007) find that OFDI decreases with distance. Figure 4 provides a scatter plot of China's OFDI and distance to a third country. It reveals that a rise in China's distance to a third country implies an increasing cost of investment and hence a decline in OFDI. 
Figure 4: The relationship between China's OFDI and the distance to a third country Note: Regression results are significant at the $1 \%$ level.

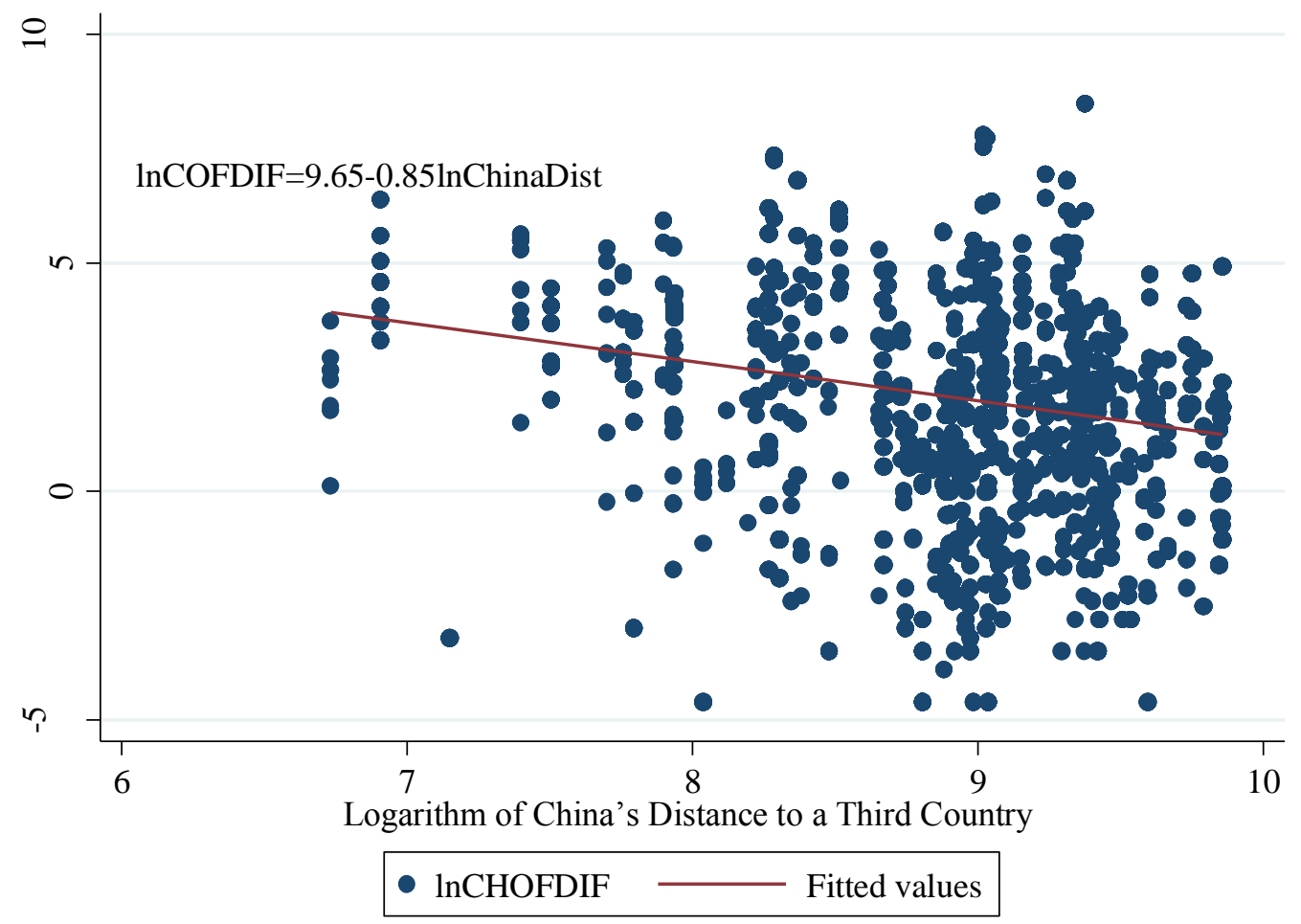

Data sources: MOFCOM (2009) and CEPII Distance Database (2010).

Second IV: China's bilateral real exchange rate (InChinaExch)

The second IV is included to overidentify the IVs' coefficients; otherwise exact justification implies that IV's exogeneity cannot be tested.

China's bilateral real exchange rate is defined as the number of units of a host country's currency per Chinese RMB, meaning that a rise in its value implies RMB appreciation, and vice versa.

The relationship between the bilateral exchange rate and FDI has been well documented from the position of three aspects: change, volatility and expectation of the bilateral exchange rate. 
The first strand of literature examines the impact of home country currency appreciation and host country currency depreciation on FDI flows (Froot and Stein, 1991; Klein and Rosengren, 1994 and Blonigen, 1997). The second strand of literature investigates the response of FDI flows to exchange rate volatility, especially when a currency is in crisis (Lipsey, 2001; Desai et al., 2004). The final strand of literature studies the response of FDI flows to an expected change in exchange rates (Campa, 1993; Goldberg and Kolstad, 1995).

Whether China's bilateral real exchange rate is an appropriate IV is further justified by its relevance and exogeneity. Being a relevant IV, China's bilateral real exchange rate should have a close relationship with OFDI. Figure 5 provides a scatter plot of these two variables, showing a plausible correlation. A rise in the real exchange rate implies RMB's appreciation, resulting from an increase in OFDI.

Figure 5: Relation between China's bilateral real exchange rate and OFDI 


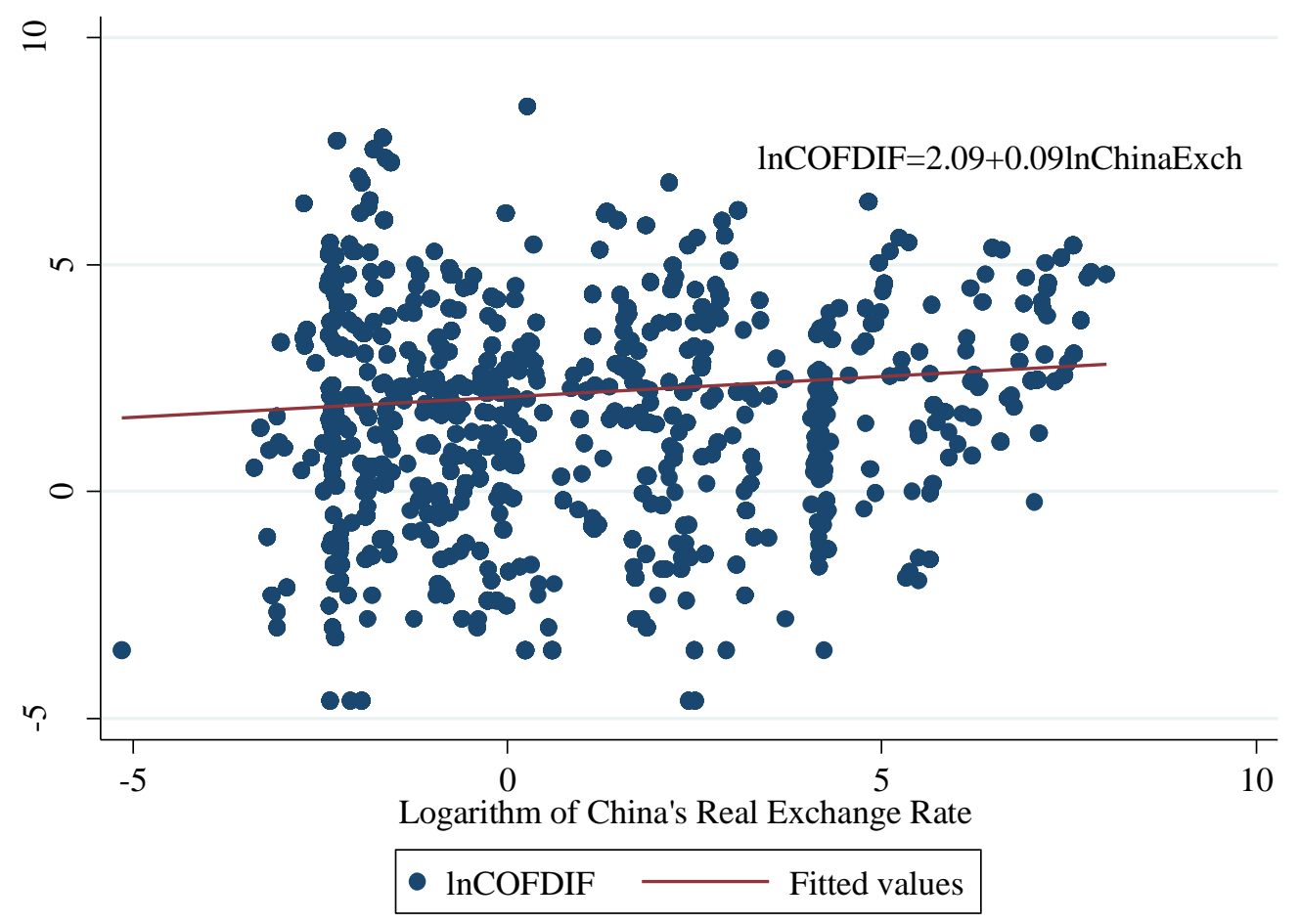

Notes: China's bilateral real exchange rates with host countries are calculated by the authors. Regression results are significant at the $1 \%$ level.

Data sources: MOFCOM (2009) and World Bank's World Development Indicators (various years).

Exogeneity of the selected IV implies no correlation between the real change rate and the OFDI of the OECD countries. However, this exclusion restriction might be violated if the IV is correlated with other unobserved factors which also affect the OFDI of OECD countries. For example, if the US dollar depreciates against Chinese $\mathrm{RMB}$, it also depreciates against the host country's currency at the same time. Therefore, the IV is only valid when the exclusion restriction assumption holds and the result obtained crucially depends on the assumption of the IV's validity.

To account for this possibility, this study controls for the logarithm of the OECD's real exchange rate with a third country $(\operatorname{lnExch})$ in Equation (1). In addition, China's foreign exchange reforms in 2005 serve as an exogenous shock which improves the instrument's exogeneity, because the change in China's exchange rate policy should have little impact on an OECD country's exchange rate with the host country. 
In short, the distance from China to a third country and the real exchange rate between Chinese RMB and a third country's currency are valid IVs. Their validity is supported by a series of statistical tests. A sufficiently large first-stage F-statistic indicates that the IVs are exogeneous. The Kleibergen-Paap rk test provides an additional check for under-identification, a strong rejection implying that the IVs are relevant. The failure to reject the Hansen overidentification test ensures that the IVs are uncorrelated with residuals, confirming their exogeneity.

\section{Data and empirical models}

The bilateral country-level OFDI data for the OECD countries are obtained from the OECD International Direct Investment Statistics database. China's bilateral countrylevel OFDI data are obtained from the Ministry of Commerce Statistical Bulletin of China's Outward Foreign Direct Investment.

The World Bank's World Development Indicators provide data for the following variables: (1) Real GDP and real GDP per capita for both home and host countries, which are deflated to constant 2000 US dollar prices; (2) Technology and resource abundance; (3) Bilateral real exchange rates. Data for distance, land area, whether a country is landlocked, colonial links, common coloniser, common language, same country and contiguity are collected from the CEPII Distances Database.

A panel dataset of OFDI flows between 155 host countries and 33 OECD home countries during 2003-2009 is constructed. All the host and home countries are listed 
in Tables A1 and A2 in Appendix A. Mexico is dropped from the home country list because of missing data.

The dataset is cleaned using three criteria: (1) omitting observations with negative or missing data; (2) omitting data from the Cayman Islands, British Virgin Islands, Hong Kong and Macao, which are subject to 'round tripping'; (3) the dependent variable, the OFDI of OECD countries, is winsorised at $1 \%$ using the two tails of the distribution. Winsorisation is a systematic approach to remove outliers and so any observation beyond the computed critical value is deleted. The cleaned dataset includes 9,283 observations or $76 \%$ of all the original observations without cleaning.

The summary statistics for all variables are provided in Table 1, including OECD's OFDI, China's OFDI, host country and home country characteristics, host-home country bilateral characteristics and IVs.

Table 1: Summary statistics (33 OECD countries, 155 host countries, 2003-2009)

\begin{tabular}{lccccc}
\hline Variable & $\mathrm{N}$ & Mean & S.D. & Minimum & Maximum \\
\hline lnOECDOFDIF & 9283 & 3.47 & 2.90 & -3.82 & 9.74 \\
lnCOFDIF & 7111 & 2.05 & 2.47 & -4.61 & 8.48 \\
\hline Host country characteristics $(i)$ & 8958 & 11.33 & 2.03 & 4.78 & 16.3 \\
\hline lnRGDP & 8958 & 8.59 & 1.51 & 4.42 & 11.33 \\
lnRGDPPC & 8115 & 0.13 & 0.13 & 0 & 1.00 \\
Technology & 8026 & 0.23 & 0.26 & 0 & 1.00 \\
Resources & 9235 & 12.87 & 1.70 & 8.86 & 16.26 \\
\hline Home country's characteristics $(j)$ & 9.96 & 0.62 & 8.31 & 10.94 \\
\hline lnRGDP & 9235 & 0.17 & 0.09 & 0.02 & 0.57 \\
lnRGDPPC & 9032 & 0.09 & 0.09 & 0.01 & 0.75 \\
Technology & 8841 & & & & 17.78 \\
Resources & & 1.04 & 3.46 & -8.30 & 32.72 \\
\hline Bilateral characteristics $(j i)$ & 7776 & 24.25 & 2.89 & 11.83 & 1 \\
\hline lnExch & 9218 & 0.07 & 0.25 & 0 & 1 \\
lnArea & 9218 & 0.01 & 0.07 & 0 & \\
Colony & 9198 & & & & \\
Comcol & & & & & \\
\hline
\end{tabular}




\begin{tabular}{lccccc} 
Comlang & 9218 & 0.10 & 0.30 & 0 & 1 \\
Contig & 9218 & 0.05 & 0.22 & 0 & 1 \\
lnDist & 9218 & 8.20 & 1.05 & 4.09 & 9.89 \\
Smctry & 9218 & 0.01 & 0.12 & 0 & 1 \\
\hline Instruments & & & & 9.86 \\
\hline lnChinaDist & 9283 & 8.93 & 0.55 & 6.73 & 15.07 \\
lnChinaExch & 8226 & 0.05 & 2.61 & -5.15 & \\
\hline
\end{tabular}

Notes: $\mathrm{N}=$ number of observations. S.D. = standard deviation. Values are measured in current prices in \$ million (OECDOFDIF, COFDIF); in 2000 price US dollar (RGDP, RGDPPC); in percentage (Resources, Technology); in units of local currency per OECD country's and China's currency (Exch, ChinaExch); in KM (ChinaDist, Dist); in $\mathrm{KM}^{2}$ (Area); in binary value (Colony, Comcol, Comlang, Contig, Smctry).

Data sources: OECD's International Direct Investment Statistics, MOFCOM (2009), World Bank's World Development Indicators (various years), and CEPII (2010).

\section{Empirical results}

Equation (1) is estimated under various specifications to examine whether and how the results vary with different control variables. Table 2 reports the results.

Model 1 in column (1) shows results using the full sample. The main explanatory variable, China's OFDI, is negative and significant at the $1 \%$ level. It suggests that a $10 \%$ rise in China's OFDI causes a 1.64\% drop in the OFDI of OECD countries. The host country market effect measurements, real GDP and real GDP per capita, are both positive and significant at the $1 \%$ level. They imply that the OFDI of OECD countries is driven by the market-seeking motivation, consistent with Dunning $(1993,1998)$. The home country's real GDP per capita is positive and significant at the $10 \%$ level. This reflects the strength of home country to invest overseas as illustrated by Dunning (1981, 1995) and Dunning et al. (2001), although the home country's real GDP is positive and insignificant.

The real exchange rate of OECD countries is negative and significant at the 5\% level, consistent with the findings of existing studies which argue that home country 
currency depreciation helps overseas investments (Cushman, 1985; Summary and Summary, 1995; Goldberg and Klein, 1998). Other bilateral control variables, including colonial link, common coloniser, common language and contiguity, all have positive and significant effect on the OFDI of OECD countries. This positive effect implies that the OFDI of OECD countries is positively correlated with economic approximation. The bilateral distance demonstrates a negative and significant effect. 
Table 2: TSLS estimation using full data sample

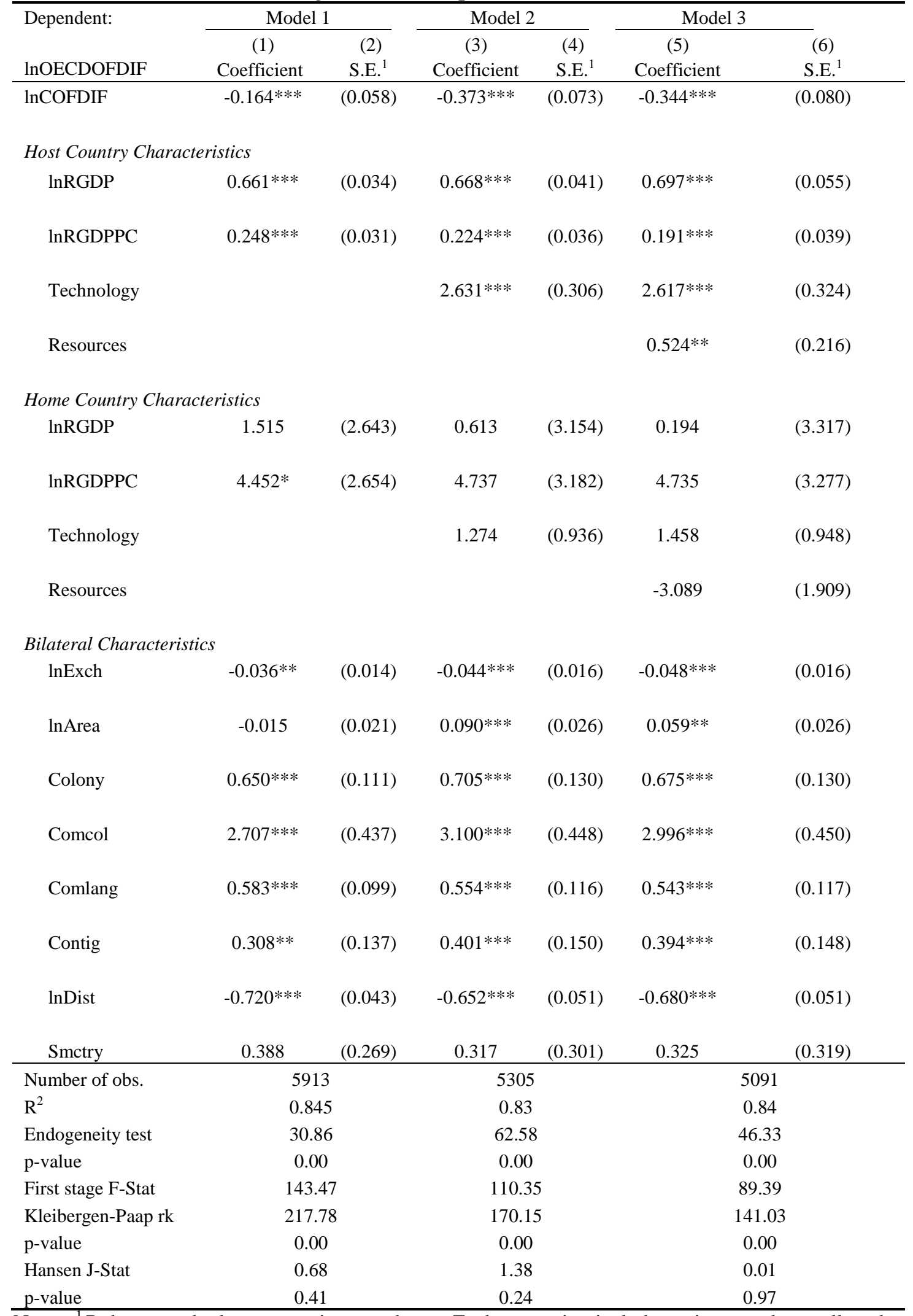

Notes: ${ }^{1}$ Robust standard errors are in parentheses. Each regression includes a time trend as well as the home country dummy. Significant at $* 10 \%, * * 5 \%$ and $* * * 1 \%$. 
Model 2 includes host country and home country technology levels apart from those included in Model 1. The results strengthen the replacement effect of China's OFDI on OECD's OFDI, as a $10 \%$ rise in the former will now lead to a $3.73 \%$ drop in the latter. Host country technology level is positive and significant at the $1 \%$ level, implying a clear technology-seeking motivation, consistent with Driffield and Love (2003). In contrast, home country technology level is found to have a positive but insignificant effect.

Models 1 and 2 might be mis-specified as they have not considered the effect of resource-seeking motivation, which is argued to have a strong effect on China's OFDI decision (Yao, et al., 2010). Model 3 adds both the host country and home country resource endowment levels apart from those included in Model 2.

China's OFDI is still found to have a negative and significant effect at the $1 \%$ level and its marginal impact on the OFDI of OECD countries is similar to that found in Model 2. The additional explanatory variable, host country resource endowment, is positive and significant at the 5\% level, although home country resource endowment is found to have an insignificant effect.

In summary, regression results of the three different specifications of the basic model reveal a significant displacement effect of China's OFDI on the OFDI of OECD countries, with a replacement elasticity ranging from 0.164 to 0.373 .

The first stage regression result is reported in Table B1 in Appendix B. Although the first IV, China's distance to a third country (lnChinaDist), is negative and significant 
at the $1 \%$ level, the second IV, China's bilateral real exchange rate (InChinaExch), is positive but insignificant. The insignificance of IV might imply that the finding of the displacement effect in Table 2 depends on the validity of IV. To further investigate this displacement effect in the following regressions, the whole sample is split by using different criteria including host country resource endowment, continental location and income level, respectively.

Given the importance of natural resources to China's OFDI (Yao et al., 2010; Buckley et al., 2007), another research question to be asked is whether the displacement effect of China's OFDI on the OFDI of OECD countries in a host country is conditional on oil/ore abundance. To answer question, the whole sample is split into oil/ore abundant countries and countries that are less abundant in oil/ore. ${ }^{5}$

The variation of displacement effect with oil abundance of a host country is first presented in columns (1) and (2) in Table 3. For oil abundant countries (column 1), interestingly, there is no evidence of displacement effect. The coefficient on China's OFDI is insignificant, meaning that for this group of countries, Chinese overseas investments do not displace those of OECD countries.

There are two possible explanations for this result. Firstly, China's presence in oil abundance countries is resisted by the West (Chen, 2008). China's oil companies are unable to penetrate the most easily extractable countries because the West has had a

\footnotetext{
${ }^{5}$ Oil abundance is defined by the share of oil's production in GDP. A host country is oil abundant if this share exceeds its median value; otherwise, it is less oil abundant. Ore abundance is defined by the share of ores and metal exports in merchandise exports, as is in the World Bank World Development Indicators. A host country is ore-abundant if this share exceeds its median value.
} 
long held dominance. For instance, Saudi Arabia has a very long and close relationship with the West and oil plays a significant role in their bilateral relationship.

Secondly, China's OFDI in other oil-rich countries that have been placed under punitive sanction regimes by the West has little impact on the OFDI of OECD countries in these particular countries. For instance, Iran has had a poor economic and diplomatic relationship with the US since 1979. The Iranian Revolution and the Iranian hostage crisis led to mutual enmity in the American-Iranian relationship in all areas.

The estimated results for host countries that are less abundant in oil are presented in column (2) in Table 3. The results show evidence of a displacement effect, as the coefficient on China's OFDI is negative and significant at the 5\% level. This implies that a $10 \%$ rise in China's OFDI will cause a drop in the OFDI of OECD countries of 6.53\%. This displacement effect could be explained as the result of market competition. The market-seeking motivation drives OFDI from China as well as from OECD countries. The displacement effects of China's OFDI on the OFDI of OECD countries in those that are ore-abundant and less-abundant are presented in column (3) and (4) in Table 3. The results are not dissimilar to those presented in columns (1) and (2) for oil-abundant and oil less-abundant host countries. ${ }^{6}$

Overall, the estimates results in Table 3 indicate that China's OFDI displaces the OFDI of OECD countries in those that are less abundant in natural resources rather than those that are resource abundant.

\footnotetext{
${ }^{6}$ The interpretation of the insignificant displacement in metal abundant countries needs to be treated with caution because of the failure to reject the endogeneity test.
} 
This finding seems surprising, especially after addressing the importance of China's resource-seeking motivation. The above explanation indicates that the long held dominance of the West serves to restrict China's OFDI in natural resource abundant countries. Of course, China's OFDI might displace the OFDI of certain OECD countries, but there is no systematic evidence of a displacement effect in all countries. The displacement effect in countries that are less abundant in natural resources could be driven by the market-seeking motivation.

The whole sample is alternatively split according to host country incomes and continental location in the following regressions to further investigate whether the displacement effect varies with other characteristics. The estimations based on these two criteria in the following examinations have yielded consistent results because these two classifications are closely related. High-income countries are generally located in Europe and North America and low-income countries largely exist in Africa and Latin America.

Columns (5) and (6) in Table 3 report the regression results when the sample is split into high- and low-income countries. ${ }^{7}$ The coefficient on China's OFDI is negative and significant at the $1 \%$ level, implying that a $10 \%$ rise in China's OFDI will cause a $5.32 \%$ decline in OECD's OFDI in high-income host countries.

As an important measure of market effect, the higher level of host country income would tend to attract more FDI, be it from China or the OECD. China's marketseeking motivation is indirectly reflected in an empirical study claiming that China's

\footnotetext{
${ }^{7}$ The income level is measured by real GDP per capita. A host country is a high-income country if this value exceeds the median value; otherwise, it is a low-income country.
} 
exports displace that of other Asian nations to high-income countries (Greenaway et al., 2008). In addition, the importance of market-seeking motivation is jointly witnessed by China's export-oriented economy and a close relationship between China's OFDI and exports. ${ }^{8}$ Therefore, market competition results in a displacement effect of China's OFDI on that of OECD countries in high-income host countries.

Column (6) in Table 3 shows the estimation results for low-income host countries. They show no evidence of displacement effect. It may suggest that low-income host countries may not be attractive to Chinese companies. Less competition between China and OECD for their investments may explain why the displacement effect is insignificant.

Column (7) in Table 3 shows the estimation results for the host countries located in Asia. The displacement effect is significant at the 5\% level, implying a $10 \%$ rise in China's OFDI will cause a 3.85\% drop in Asian OECD countries.

Estimation results for the host countries located in Europe and North America are reported in column (9) in Table 3. They imply that the displacement effect is significant at the $1 \%$ level, meaning that a $10 \%$ rise in China's OFDI will cause a $3.55 \%$ drop in European and North American OECD host countries by the other OECD countries. These significant displacement effects coincide with the abovementioned argument, whereby the market-seeking motivation drives Chinese and OECD countries' OFDI to flow into big markets including Asia, Europe and North America.

\footnotetext{
${ }^{8}$ In 2009, the rent and business service industry, the wholesale and retail industry and the transportation industry occupied $36.2 \%, 10.8 \%$ and $3.7 \%$ of China's OFDI respectively. Overall, $50.7 \%$ of China's OFDI was directed to exports-related industries (MOFCOM, 2009).
} 
On the contrary, estimations for the host countries located in Africa, Latin America and Oceania (column 8, Table 3) do not show any displacement effect. This can be explained by the joint effect of resource-seeking and market-seeking motivations revealed in columns (1)-(6) in Table 3 . Host countries located in these continents, especially Africa, are generally acknowledged as low income with abundant resources. Motivation of market-seeking is relatively weak compared to resource-seeking for Chinese companies.

Besada et al. (2008) suggest that China's OFDI in Africa focuses primarily on obtaining natural resources. Cheung et al. (2011) argue that energy abundance attracts Chinese investments in Africa, whereas Western countries have conventionally invested relatively small amounts to avoid risk. In contrast, the OECD countries' overseas investments may have been motivated by a need for diversification, which explains why China's presence in Africa and Latin America may have little impact on the OECD countries as far as foreign investments are concerned.

In short, the displacement effect is conditional on the host country's incomes and continental location. Market-seeking may drive China's OFDI flow into high-income, Asian, European and North American countries, but there is little evidence of China displacing OECD countries' OFDI in low-income, African, Latin American and Oceanian countries. 
Table 3: The Effects of Host Country's Characteristics on the Displacement Effect

\begin{tabular}{|c|c|c|c|c|c|c|c|c|c|}
\hline \multirow{4}{*}{$\begin{array}{l}\text { Dependent: } \\
\text { lnOECDOFDIF }\end{array}$} & \multicolumn{4}{|c|}{ Natural Resources } & \multicolumn{2}{|c|}{ Income } & \multicolumn{3}{|c|}{ Continental Location } \\
\hline & \multirow{2}{*}{\multicolumn{2}{|c|}{ (1) }} & \multirow{2}{*}{\multicolumn{2}{|c|}{ Metal }} & \multirow[t]{2}{*}{$(5)$} & \multirow[t]{2}{*}{ (6) } & \multirow[t]{2}{*}{ (7) } & \multirow{2}{*}{$\begin{array}{c}(8) \\
\text { Africa+ }\end{array}$} & \multirow{2}{*}{$\begin{array}{c}(9) \\
\text { Europe+ }\end{array}$} \\
\hline & & & & & & & & & \\
\hline & Abundant & $\begin{array}{c}\text { Less } \\
\text { Abundant }\end{array}$ & Abundant & $\begin{array}{c}\text { Less } \\
\text { Abundant }\end{array}$ & High & Low & Asia & $\begin{array}{c}\text { Oceania+ } \\
\text { Latin America }\end{array}$ & North America \\
\hline $\operatorname{lnCOFDIF}$ & $\begin{array}{l}-0.051 \\
(0.059)\end{array}$ & $\begin{array}{c}-0.653 * * \\
(0.266)\end{array}$ & $\begin{array}{c}0.151 \\
(0.118)\end{array}$ & $\begin{array}{c}-1.099 * * * \\
(0.192)\end{array}$ & $\begin{array}{c}-0.532 * * * \\
(0.165)\end{array}$ & $\begin{array}{l}-0.014 \\
(0.064)\end{array}$ & $\begin{array}{c}-0.385 * * \\
(0.188)\end{array}$ & $\begin{array}{l}-0.058 \\
(0.077)\end{array}$ & $\begin{array}{c}-0.355^{* * * *} \\
(0.111)\end{array}$ \\
\hline \multicolumn{10}{|c|}{ Host Country Characteristics } \\
\hline $\operatorname{lnRGDP}$ & $\begin{array}{c}0.437 * * * \\
(0.043)\end{array}$ & $\begin{array}{c}1.144 * * * \\
(0.244)\end{array}$ & $\begin{array}{c}0.545^{* * *} * \\
(0.041)\end{array}$ & $\begin{array}{c}1.805 * * * \\
(0.215)\end{array}$ & $\begin{array}{c}0.763 * * * \\
(0.147)\end{array}$ & $\begin{array}{c}0.643 * * * \\
(0.041)\end{array}$ & $\begin{array}{c}0.738 * * * \\
(0.071)\end{array}$ & $\begin{array}{c}0.940 * * * \\
(0.059)\end{array}$ & $\begin{array}{c}0.858 * * * \\
(0.130)\end{array}$ \\
\hline $\operatorname{lnRGDPPC}$ & $\begin{array}{c}0.315^{* * * *} \\
(0.040)\end{array}$ & $\begin{array}{c}-0.047 \\
(0.140)\end{array}$ & $\begin{array}{c}0.317 * * * \\
(0.051)\end{array}$ & $\begin{array}{c}-0.717 * * * \\
(0.154)\end{array}$ & $\begin{array}{c}0.149 \\
(0.108)\end{array}$ & $\begin{array}{c}0.469 * * * \\
(0.057)\end{array}$ & $\begin{array}{c}0.031 \\
(0.095)\end{array}$ & $\begin{array}{c}0.150 * * \\
(0.064)\end{array}$ & $\begin{array}{l}-0.202 * \\
(0.120)\end{array}$ \\
\hline Technology & $\begin{array}{c}1.044 * * * \\
(0.267)\end{array}$ & $\begin{array}{l}1.263 * \\
(0.682)\end{array}$ & $\begin{array}{c}-0.729 * \\
(0.385)\end{array}$ & $\begin{array}{c}5.041 * * * \\
(0.687)\end{array}$ & $\begin{array}{c}6.348 * * * \\
(0.657)\end{array}$ & $\begin{array}{l}0.419 * \\
(0.250)\end{array}$ & $\begin{array}{c}3.430 * * * \\
(0.573)\end{array}$ & $\begin{array}{c}0.591 \\
(0.726)\end{array}$ & $\begin{array}{c}3.962 * * * \\
(0.656)\end{array}$ \\
\hline Resources & $\begin{array}{c}-1.044 * * * \\
(0.162)\end{array}$ & $\begin{array}{c}5.125^{* * *} \\
(1.431)\end{array}$ & $\begin{array}{c}-0.573 * * \\
(0.227)\end{array}$ & $\begin{array}{c}2.727 * * * \\
(0.516)\end{array}$ & $\begin{array}{c}-0.067 \\
(0.371)\end{array}$ & $\begin{array}{l}-0.269 \\
(0.203)\end{array}$ & $\begin{array}{c}1.003^{* *} \\
(0.415)\end{array}$ & $\begin{array}{c}-0.113 \\
(0.250)\end{array}$ & $\begin{array}{l}0.688 * \\
(0.405)\end{array}$ \\
\hline \multicolumn{10}{|c|}{ Home Country Characteristics } \\
\hline $\operatorname{lnRGDP}$ & $\begin{array}{c}2.005 \\
(4.130)\end{array}$ & $\begin{array}{l}-1.233 \\
(5.104)\end{array}$ & $\begin{array}{c}10.650 * * \\
(4.624)\end{array}$ & $\begin{array}{c}-11.500 * * \\
(5.655)\end{array}$ & $\begin{array}{l}-3.938 \\
(4.733)\end{array}$ & $\begin{array}{c}5.599 \\
(4.470)\end{array}$ & $\begin{array}{c}7.406 \\
(7.401)\end{array}$ & $\begin{array}{c}2.093 \\
(5.538)\end{array}$ & $\begin{array}{l}-5.260 \\
(4.410)\end{array}$ \\
\hline $\operatorname{lnRGDPPC}$ & $\begin{array}{c}3.442 \\
(3.957)\end{array}$ & $\begin{array}{c}4.881 \\
(5.297)\end{array}$ & $\begin{array}{l}-6.311 \\
(4.477)\end{array}$ & $\begin{array}{c}16.010 * * * \\
(5.593)\end{array}$ & $\begin{array}{l}9.200 * \\
(4.815)\end{array}$ & $\begin{array}{c}-0.448 \\
(4.360)\end{array}$ & $\begin{array}{c}-0.525 \\
(7.227)\end{array}$ & $\begin{array}{c}2.693 \\
(5.447)\end{array}$ & $\begin{array}{c}10.310 * * \\
(4.392)\end{array}$ \\
\hline Technology & $\begin{array}{c}2.356 * * \\
(1.146)\end{array}$ & $\begin{array}{c}1.073 \\
(1.490)\end{array}$ & $\begin{array}{c}2.865 * * \\
(1.233)\end{array}$ & $\begin{array}{l}-1.025 \\
(1.538)\end{array}$ & $\begin{array}{l}2.235^{*} \\
(1.255)\end{array}$ & $\begin{array}{c}0.392 \\
(1.363)\end{array}$ & $\begin{array}{l}-0.186 \\
(2.126)\end{array}$ & $\begin{array}{l}-1.909 \\
(1.362)\end{array}$ & $\begin{array}{c}2.918 * * \\
(1.229)\end{array}$ \\
\hline Resources & $\begin{array}{l}-1.171 \\
(2.021)\end{array}$ & $\begin{array}{l}-6.312^{*} \\
(3.552)\end{array}$ & $\begin{array}{l}-3.738 \\
(2.366)\end{array}$ & $\begin{array}{l}-0.217 \\
(3.527)\end{array}$ & $\begin{array}{l}-4.842 * \\
(2.761)\end{array}$ & $\begin{array}{l}-3.567 \\
(2.410)\end{array}$ & $\begin{array}{l}-2.842 \\
(3.833)\end{array}$ & $\begin{array}{l}-4.036 \\
(3.735)\end{array}$ & $\begin{array}{l}-3.353 \\
(2.532)\end{array}$ \\
\hline
\end{tabular}




\begin{tabular}{|c|c|c|c|c|c|c|c|c|c|}
\hline \multicolumn{10}{|c|}{ Bilateral Characteristics } \\
\hline $\operatorname{lnExch}$ & $\begin{array}{l}-0.022 \\
(0.017)\end{array}$ & $\begin{array}{c}0.024 \\
(0.052)\end{array}$ & $\begin{array}{l}-0.026 \\
(0.026)\end{array}$ & $\begin{array}{l}-0.001 \\
(0.028)\end{array}$ & $\begin{array}{c}-0.191 * * * \\
(0.026)\end{array}$ & $\begin{array}{l}-0.016 \\
(0.019)\end{array}$ & $\begin{array}{c}0.150 * * \\
(0.070)\end{array}$ & $\begin{array}{c}-0.098 * * * \\
(0.025)\end{array}$ & $\begin{array}{c}-0.054 \\
(0.035)\end{array}$ \\
\hline lnArea & $\begin{array}{c}0.345^{* * * *} \\
(0.051)\end{array}$ & $\begin{array}{c}-0.579 * * * \\
(0.124)\end{array}$ & $\begin{array}{c}0.047 \\
(0.069)\end{array}$ & $\begin{array}{c}-0.647 * * * \\
(0.094)\end{array}$ & $\begin{array}{l}0.071 * \\
(0.041)\end{array}$ & $\begin{array}{c}0.002 \\
(0.047)\end{array}$ & $\begin{array}{c}-0.169 * * * \\
(0.051)\end{array}$ & $\begin{array}{c}-0.299 * * * \\
(0.048)\end{array}$ & $\begin{array}{c}0.048 \\
(0.057)\end{array}$ \\
\hline Colony & $\begin{array}{c}0.364 * * \\
(0.170)\end{array}$ & $\begin{array}{c}1.122 * * * \\
(0.214)\end{array}$ & $\begin{array}{c}0.584 * * * \\
(0.179)\end{array}$ & $\begin{array}{c}0.981 * * * \\
(0.258)\end{array}$ & $\begin{array}{c}0.287 \\
(0.231)\end{array}$ & $\begin{array}{c}0.598 * * * \\
(0.159)\end{array}$ & $\begin{array}{c}-0.519 * \\
(0.265)\end{array}$ & $\begin{array}{c}1.299 * * * \\
(0.208)\end{array}$ & $\begin{array}{l}0.378 * \\
(0.213)\end{array}$ \\
\hline Comcol & $\begin{array}{c}2.642 * * * \\
(0.538)\end{array}$ & $\begin{array}{c}1.621 \\
(1.577)\end{array}$ & $\begin{array}{c}2.714 * * * \\
(0.501)\end{array}$ & $\begin{array}{c}2.004 * * \\
(0.949)\end{array}$ & $\begin{array}{c}0.978 \\
(0.754)\end{array}$ & $\begin{array}{c}2.669 * * * \\
(0.567)\end{array}$ & $\begin{array}{c}1.418 * * \\
(0.686)\end{array}$ & dropped & $\begin{array}{c}3.443 * * * \\
(0.610)\end{array}$ \\
\hline Comlang & $\begin{array}{c}0.721 * * * \\
(0.161)\end{array}$ & $\begin{array}{c}0.001 \\
(0.173)\end{array}$ & $\begin{array}{c}0.503^{* * * *} \\
(0.128)\end{array}$ & $\begin{array}{c}0.554 * * \\
(0.247)\end{array}$ & $\begin{array}{c}0.959 * * * \\
(0.208)\end{array}$ & $\begin{array}{c}0.530 * * * \\
(0.154)\end{array}$ & $\begin{array}{c}0.607 * * \\
(0.285)\end{array}$ & $\begin{array}{c}0.416^{* *} \\
(0.194)\end{array}$ & $\begin{array}{c}0.418 * * \\
(0.184)\end{array}$ \\
\hline Contig & $\begin{array}{c}1.104 * * * \\
(0.269)\end{array}$ & $\begin{array}{c}0.237 \\
(0.210)\end{array}$ & $\begin{array}{c}0.026 \\
(0.214)\end{array}$ & $\begin{array}{c}0.554 * * \\
(0.227)\end{array}$ & $\begin{array}{l}-0.151 \\
(0.196)\end{array}$ & $\begin{array}{c}1.521 * * * \\
(0.286)\end{array}$ & $\begin{array}{l}-1.012 \\
(0.666)\end{array}$ & $\begin{array}{c}1.273 * * * \\
(0.273)\end{array}$ & $\begin{array}{l}0.303 * \\
(0.162)\end{array}$ \\
\hline $\operatorname{lnDist}$ & $\begin{array}{c}-0.983 * * * \\
(0.050)\end{array}$ & $\begin{array}{c}-0.777 * * * \\
(0.104)\end{array}$ & $\begin{array}{c}-0.987 * * * \\
(0.064)\end{array}$ & $\begin{array}{c}-0.617 * * * \\
(0.081)\end{array}$ & $\begin{array}{c}-0.454 * * * \\
(0.119)\end{array}$ & $\begin{array}{c}-0.821 * * * \\
(0.056)\end{array}$ & $\begin{array}{c}-1.142 * * * \\
(0.171)\end{array}$ & $\begin{array}{c}-0.212 * * \\
(0.090)\end{array}$ & $\begin{array}{c}-0.614^{* * *} * \\
(0.084)\end{array}$ \\
\hline Smctry & $\begin{array}{l}-0.217 \\
(0.467) \\
\end{array}$ & $\begin{array}{l}-0.526 \\
(0.498) \\
\end{array}$ & $\begin{array}{l}-0.650 \\
(0.471) \\
\end{array}$ & $\begin{array}{c}0.468 \\
(0.459) \\
\end{array}$ & $\begin{array}{c}1.400 * * * \\
(0.388)\end{array}$ & $\begin{array}{r}-1.216 \\
(1.124) \\
\end{array}$ & dropped & dropped & $\begin{array}{l}0.574 * \\
(0.329) \\
\end{array}$ \\
\hline Number of obs. & 2790 & 2301 & 2468 & 2623 & 2528 & 2563 & 1285 & 1505 & 2301 \\
\hline $\mathrm{R}^{2}$ & 0.871 & 0.820 & 0.875 & 0.737 & 0.854 & 0.826 & 0.818 & 0.843 & 0.879 \\
\hline Endogeneity test & 5.584 & 14.500 & 0.000 & 88.391 & 26.985 & 5.683 & 11.177 & 8.002 & 24.384 \\
\hline $\mathrm{p}$-value & 0.018 & 0.000 & 0.985 & 0.000 & 0.000 & 0.017 & 0.001 & 0.005 & 0.000 \\
\hline First stage F-Stat & 135.086 & 11.410 & 30.050 & 31.190 & 20.170 & 132.800 & 26.590 & 75.470 & 35.280 \\
\hline Kleibergen-Paap rk & 220.274 & 19.450 & 55.740 & 54.600 & 39.530 & 206.200 & 44.720 & 157.800 & 58.940 \\
\hline p-value & 0.000 & 0.000 & 0.000 & 0.000 & 0.000 & 0.000 & 0.000 & 0.000 & 0.000 \\
\hline Hansen J-Stat & 0.602 & 1.575 & 0.860 & 0.647 & 0.132 & 0.450 & 0.007 & 1.733 & 0.186 \\
\hline p-value & 0.438 & 0.209 & 0.354 & 0.421 & 0.717 & 0.502 & 0.932 & 0.188 & 0.666 \\
\hline
\end{tabular}

Notes: Robust standard errors are in parentheses. Each regression includes a time trend as well as the home country dummy. Significant at $* 10 \%, * * 5 \%$ and $* * * 1 \%$. Smctry and Comcol were dropped in columns (7) and (8) because of the collinearities. 


\section{Robustness checks}

Two robustness checks were undertaken to examine the sensitivity of results to various aspects including the involvement of SARs as destinations and the estimation period before the 2008 financial crisis.

Two special administrative regions (SARs), Hong Kong and Macao, are excluded from the previous estimations because they are acknowledged as tax havens and investments of OECD countries in these destinations may suffer from the 'roundtripping' problem. However, China's OFDI skews towards SARs because of the historical relations between them. The exclusion of SARs may lead to biased estimates of the displacement effect.

Column (1) in Table 4 presents the estimation result with inclusion of SARs as destinations, but the coefficient on China's OFDI is still found to be negative and significant at the $1 \%$ level.

The sample period 2003-2009 includes two years of the world financial crisis, 2008 and 2009. The financial crisis was initially triggered by the US subprime crisis and rapidly spread to the world and substantially changed the global economic landscape. For example, the OFDI of OECD countries contracted sharply by $18 \%$ and $47 \%$ in 2008 and 2009, respectively. In contrast, China's OFDI expanded by $111 \%$ and $1 \%$, respectively. ${ }^{9}$

\footnotetext{
${ }^{9}$ The growth rates were calculated by the authors. Data for the OECD countries' OFDI were obtained from the UNCTAD World Investment Report (various issues). Data for China's OFDI were obtained from the MOFCOM (2009).
} 
To examine the effect of the crisis on China's OFDI, the dataset for 2003-2007 was re-estimated this time excluding the observations for 2008-2009. The results do not alter the sign and statistical significance of the main variable of interest, and the magnitude of the estimated coefficient is also similar (column (3), Table 4). 
Table 5: Results of the Robustness Checks

\begin{tabular}{|c|c|c|c|c|}
\hline \multirow{3}{*}{$\begin{array}{l}\text { Dependent: } \\
\text { lnOECDOFDIF }\end{array}$} & \multicolumn{2}{|c|}{ Including SARs } & \multicolumn{2}{|c|}{ Pre-Crisis } \\
\hline & $(1)$ & (2) & $(3)$ & (4) \\
\hline & Coefficient & S.E. ${ }^{1}$ & Coefficient & S.E. ${ }^{1}$ \\
\hline $\operatorname{lnCOFDIF}$ & $-0.111 * * *$ & $(0.039)$ & $-0.422 * * *$ & $(0.102)$ \\
\hline \multicolumn{5}{|c|}{ Host Country Characteristics } \\
\hline $\operatorname{lnRGDP}$ & $0.622 * * *$ & $(0.042)$ & $0.675^{* * *} *$ & $(0.063)$ \\
\hline lnRGDPPC & $0.195 * * *$ & $(0.035)$ & $0.235^{* * *} *$ & $(0.044)$ \\
\hline Technology & $1.871 * * *$ & $(0.236)$ & $3.303 * * *$ & $(0.409)$ \\
\hline Resources & 0.111 & $(0.158)$ & $0.604 * *$ & $(0.270)$ \\
\hline \multicolumn{5}{|c|}{ Home Country Characteristics } \\
\hline $\operatorname{lnRGDP}$ & 0.734 & $(3.048)$ & 1.736 & $(4.606)$ \\
\hline lnRGDPPC & 4.150 & $(3.011)$ & 1.362 & $(4.582)$ \\
\hline Technology & $1.698 *$ & $(0.890)$ & 1.342 & $(1.081)$ \\
\hline Resources & $-3.087 *$ & $(1.728)$ & -3.918 & $(3.074)$ \\
\hline \multicolumn{5}{|c|}{ Bilateral Characteristics } \\
\hline $\operatorname{lnExch}$ & $-0.065 * * *$ & $(0.014)$ & -0.026 & $(0.021)$ \\
\hline lnArea & -0.015 & $(0.023)$ & $0.117 * * *$ & $(0.031)$ \\
\hline Colony & $0.593 * * *$ & $(0.120)$ & $0.799 * * *$ & $(0.149)$ \\
\hline Comcol & $2.590 * * *$ & $(0.512)$ & $3.142 * * *$ & $(0.490)$ \\
\hline Comlang & $0.517 * * *$ & $(0.103)$ & $0.357 * * *$ & $(0.130)$ \\
\hline Contig & $0.319 * *$ & $(0.138)$ & $0.725^{* * *}$ & $(0.169)$ \\
\hline $\operatorname{lnDist}$ & $-0.744 * * *$ & $(0.040)$ & $-0.657 * * *$ & $(0.058)$ \\
\hline Smctry & 0.392 & $(0.279)$ & -0.109 & $(0.377)$ \\
\hline Number of obs. & \multicolumn{2}{|c|}{5,207} & \multicolumn{2}{|c|}{4,071} \\
\hline $\mathrm{R}^{2}$ & \multicolumn{2}{|c|}{0.86} & \multicolumn{2}{|c|}{0.82} \\
\hline Endogeneity test & \multicolumn{2}{|c|}{46.69} & \multicolumn{2}{|c|}{39.04} \\
\hline $\mathrm{p}$-value & \multicolumn{2}{|c|}{0.00} & \multicolumn{2}{|c|}{0.00} \\
\hline First stage F-Stat & \multicolumn{2}{|c|}{251.83} & \multicolumn{2}{|c|}{57.49} \\
\hline Kleibergen-Paap rk & \multicolumn{2}{|c|}{302.80} & \multicolumn{2}{|c|}{91.56} \\
\hline p-value & \multicolumn{2}{|c|}{0.00} & \multicolumn{2}{|c|}{0.00} \\
\hline Hansen J-Stat & \multicolumn{2}{|c|}{0.08} & \multicolumn{2}{|c|}{0.04} \\
\hline p-value & \multicolumn{2}{|c|}{0.77} & \multicolumn{2}{|c|}{0.84} \\
\hline
\end{tabular}




\section{Conclusions}

This study examines whether and how rapid growth of China's OFDI displaces OECD countries' OFDI in a third host country. A panel dataset is constructed covering OFDI flows from 33 OECD countries to 155 host countries during 20032009. A basic gravity model is also constructed to estimate the effects of China's OFDI on OECD countries' OFDI with various specifications, including different sets of control variables. A TSLS method is used for the estimation of the empirical models.

It further investigates whether and how this displacement effect varies across host country characteristics, such as resource abundance, incomes and continental location.

The empirical results suggest that China's OFDI displaces the OFDI of OECD countries in general. Depending on IV validity, a 10\% rise in China's OFDI reduces that of OECD countries by $3.4 \%$ in a third host country. However, this displacement effect responds differently to a host country's characteristics. In particular, there are significant displacement effects in less resource abundant, higher income host countries and those located in Asia, Europe and North America, but not in resource abundant, low-income countries and those located in Africa or Latin America. The latter findings of these insignificant displacement effects contrast with the often cited argument that China's investments in these countries are driven by a 'new colonialism', where China aims to crowd out Western investors. 
An important implication of this study in the understanding of China's overseas investments is that China displaces the OECD countries' investments in general. However, China's overseas investments do not undermine the investments of OECD countries in resource abundant, low income, African or Latin American host countries. Therefore, a more transparent OFDI policy and more government level cooperation would be helpful in clarifying the anxiety surrounding Chinese OFDI and in removing the perception that Chinese OFDI is a threat to the existing interests of other countries or that it will cause disorder in the world economy. In reality, China's OFDI is driven by common motivations and Chinese capital provides an opportunity to sustain global economic growth and to achieve mutual benefits. 


\section{References}

Anderson, J. (1979). A Theoretical Foundation for the Gravity Equation. American Economic Review, 69(1), 106-116.

Asiedu, E. (2006). Foreign Direct Investment in Africa: The Role of Natural Resources, Market Size, Government Policy, Institutions and Political Instability. World Economy, 29(1), 63-77.

Bergstrand, J. H. (1985). The Gravity Equation in International Trade - Some Microeconomic Foundations and Empirical Evidence. The Review of Economics and Statistics, 67(3), 474-481.

Bergstrand, J. H. (1989). The Generalized Gravity Equation, Monopolistic Competition, and the Factor-Proportions Theory in International Trade. The Review of Economics and Statistics, 71(1), 143-153.

Blonigen , B. A. (1997). Firm-Specific Assets and the Link between Exchange Rates and Foreign Direct Investment. American Economic Review, 87(3), 447-465.

Braconier, H., Norbäck, P. J. and Urban, D. (2002). Vertical FDI Revisited. Research Institute of Industrial Organization (IUI) Working Paper No. 579.

Buckley, P. J. and Casson, M. (1981). The Optimal Timing of Foreign Direct Investment. The Economic Journal, 91(361), 75-87.

Buckley, P. J., Clegg, L. J., Cross, A. R., Liu, X., Voss, H. and Zheng, P. (2007). The Determinants of Chinese Outward Foreign Direct Investment. Journal of International Business Studies, 38, 499-518.

Buckley, P. J., Cross, A. R., Tan, H., Xin, L. and Voss, H. (2008). Historic and Emergent Trends in Chinese Outward Direct Investment. Management International Review, 48(6), 715-748.

Campa, J. M. (1993). Entry by Foreign Firms in the US under Exchange Rate Uncertainty. The Review of Economics and Statistics, 75(4), 614-622.

CEPII. (2010). Distance Database. [Online]. Available at http://www.cepii.fr/anglaisgraph/bdd/distances.htm [accessed: 1 September 2010].

Chen, S. F. (2008). China's Outward FDI and Energy Security. East Asian Institute of National University of Singapore Working Paper No. 143.

Cheng, L. K. and Ma, Z. (2007). China's Outward FDI: Past and Future. School of Economics of Renmin University Working Paper No. 2007706001E.

Cheung, Y. W. and Qian, X. W. (2009). The Empirics of China's Outward Direct Investment. Pacific Economic Review, 14(3), 312-341. 
Cheung, Y. W., Haan, J., Qian, X. W. and Yu, S. (2011). China's Outward Direct Investment in Africa. HKIMR Working Paper No. 13/2011.

Child, J. and Rodrigues, S. (2005). The Internationalization of Chinese Firms: A Case for Theoretical Extension? Management and Organization Review, 1(3), 381-410.

CNN. (2009). It's China's World. (We just live in it). [Online]. Available at http://money.cnn.com/2009/10/07/news/international/china_natural_resources.fort une/ [accessed: October $\left.8^{\text {th }} 2009\right]$ ].

Cushman, D. O. (1985). Real Exchange Rate Risk, Expectations, and the Level of Direct Investment. The Review of Economics and Statistics, 67(2), 297-308.

Deadorff, A. V. (1995). Determinants of Bilateral Trade: Does Gravity Work in a Neoclassical World? NBER Working Paper No.5377.

Desai, M. A., Foley, F. C. and Forbes, K. J. (2004). Financial Constraints and Growth: Multinational and Local Firm Responses to Currency Crises. NBER Working Paper No. 10545.

Driffield, N. and Love, J. H. (2003). Foreign Direct Investment, Technology Sourcing and Reverse Spillovers. The Manchester School, 71(6), 659-672.

Dunning, J. H. (1981). Explaining the International Direct Investment Position of Countries: Toward a Dynamic and Development Approach. Weltwirtschaftliches Archiv, 117(1), 30-64.

Dunning, J. H. (1993). Multinational Enterprises and the Global Economy. New York: Addison-Wesley.

Dunning, J. H. (1995). What's Wrong-and Right-with Trade Theory? International Trade Journal, 9(2), 163-202.

Dunning, J. H. (1998). Location and the Multinational Enterprise: A Neglected Factor? Journal of International Business Studies, 29(1), 45-66.

Dunning, J. H., Kim, C. and Lin, J. (2001). Incorporating Trade Ratio into the Investment Development Path: A Case Study of Korea and Taiwan. Oxford Development Studies, 29(2), 145-154.

Eichengreen, B., Rhee, Y. and Tong, H. (2007). China and the Exports of Other Asian Countries. Review of World Economics, 143(2), 201-226.

Evenett, S. J. and Keller, W. (2002). On Theories Explaining the Success of the Gravity Equation. Journal of Political Economy, 110 (2), 281-316.

Fosfuri, A. and Motta, M. (1999). Multinationals without Advantages. The Scandinavian Journal of Economics, 101(4), 617-630. 
Froot, K. and Stein, J. (1991). Exchange Rates and Foreign Direct Investments: An Imperfect Capital Markets Approach. The Quarterly Journal of Economics, 106(4), 1191-1217.

Gastanaga, V., Nugent, J. and Pashamiova, B. (1998). Host Country Reforms and FDI Inflows: How Much Difference Do They Make? World Development, 26(7), 1299-1314.

Goldberg, L. S. and Klein, M. (1998). Foreign Direct Investment, Trade and Real Exchange Rate Linkages in Developing Countries, in Managing Capital Flows and Exchange Rates; Perspectives from the Pacific Basin, edited by R. Glick. Cambridge: Cambridge University Press, 73-100.

Goldberg, L. S. and Kolstad, C. D. (1995). Foreign Direct Investment, Exchange Rate Variability and Demand Uncertainty. International Economic Review, 36(4), 855873.

Greenaway, D., Mahabir, A. and Milner, C. (2008). Has China Displaced other Asian Countries' Exports? China Economic Review, 19(2), 152-169.

Helpman, E. (1987). Imperfect Competition and International Trade: Evidence from Fourteen Economies. Journal of the Japanese and International Economies, 1, 62-81.

Hummels, D. and Levinsohn, J. (1995). Monopolistic Competition and International Trade: Reconsidering the Evidence. Quarterly Journal of Economics, 110(3), 799-836.

Klein, M. and Rosengren, E. (1994). The Real Exchange Rate and Foreign Direct Investment in the United States: Relative Wealth vs. Relative Wage Effects. Journal of International Economics, 36, 373-389.

Kolstad, I. and Wiig, A. (2009). What Determines Chinese Outward FDI? CMI Working Paper 2009:3.

Lane, P. R. (2000). International Investment Positions: A Cross-Sectional Analysis. Journal of International Money and Finance, 19(4), 513-534.

Lipsey, R. E. (1999). The Location and Characteristics of U.S. Affiliates in Asia. NBER Working Paper No. 6876.

Lipsey, R. E. (2001). Foreign Direct Investment in Three Financial Crises. NBER Working Paper No. 8084.

Minister of Commerce (MOFCOM). (2009). 2009 Statistical Bulletin of China's Outward Foreign Direct Investment. [Online]. Available at http://hzs.mofcom.gov.cn/accessory/201009/1284339524515.pdf [accessed: 20 November 2010]. 
Mock, R., Yeung, B. and Zhao, M. (2008). Perspectives on China's Outward Foreign Direct Investment. Journal of International Business Studies, 39(3), 337-350.

National Bureau of Statistics (NBS). (various years). China Statistical Yearbook, China Statistical Press, Beijing.

Noorbakhsh, F., Paloni, A. and Youssef, A. (2001). Human Capital and FDI Inflows to Developing Countries: New Empirical Evidence. World Development, 29 (9), 1593-1610.

OECD. (various years). International Direct Investment Statistics. [Online]. Available at $\quad$ http://stats.oecd.org/Index.aspx?DatasetCode=FDI_FLOW_PARTNER [accessed: 20 October 2010].

OECD. (1996). Benchmark Definition of Foreign Direct Investment. 3rd Edition. Paris.

OECD. (2008). OECD Investment Policy Reviews-China 2008: Encouraging Responsible Business Conduct. OECD Investment Policy Reviews.

Park, K. H. (2003). Patterns and Strategies of Foreign Direct Investment: The Case of Japanese Firms. Applied Economics, 35(16), 1739-1746.

Rosen, D. H. and Hanemann, T. (2009). China's Changing Outbound Foreign Direct Investment Profile: Drives and Policy Implications. Peterson Institute for International Economics No. PB09-14.

Siotis, G. (1999). Foreign Direct Investment Strategies and Firms' Capabilities. Journal of Economics and Management Strategy, 8(2), 251-270.

Summary, R. M. and Summary, L. J. (1995). The Political Economy of United States Foreign Direct Investment in Developing Countries: An Empirical Analysis. Quarterly Journal of Business and Economics, 34(3), 80-92.

Taylor, I. (2007). Unpacking China's Resource Diplomacy in Africa, Centre on China's Transnational Relations. Center on China's Transnational Relations Working Paper No. 19.

The Economist. (2008). The New Colonialists: China's Hunger for Natural Resources. [Online]. Available at http://www.economist.com/node/10853534 [accessed: March 13 $\left.{ }^{\text {th }} 2008\right]$.

The Economist. (2009). China's "Going Out" Strategy. [Online]. Available at http://www.economist.com/blogs/freeexchange/2009/07/chinas_going_out_strateg y [accessed: July $21^{\text {st }} 2009$ ].

The Economist. (2010). Chinese Acquisitions: China Buys up the World, and the World should Stay Open for Business. [Online]. Available at http://www.economist.com/node/17463473 [accessed: November $11^{\text {th }} 2010$ ]. 
Tinbergen, J. (1962). Shaping the World Economy. New York: Twentieth Century Fund.

UNCTAD. (various years). World Investment Report, United Nations, New York and Geneva.

UNCTAD. (2010). World Investment Prospects Survey 2010 - 2012, United Nations, New York and Geneva.

Voss, H., Buckley, P. and Cross. A. (2008). Thirty Years of Chinese Outward Foreign Direct Investment. CEA (UK) conference: Three Decades of Economic Reform (1978-2008), Cambridge University, Cambridge (UK), 1-2 April 2008.

World Bank. (various years). World Development Indicators, World Bank, Washington, DC.

Xiao, J. and Sun, F. (2005). The Challenges Facing Outbound Chinese M\&A. International Financial Law Review, 24(12), 44-46.

Yao, S. J. and Sutherland, D. (2009). Chinalco and Rio Tinto: A Long March for China's National Champions. The China Quarterly, 199, 829-836.

Yao, S. J., Sutherland, D. and Chen, J. (2010). China's Outward FDI and ResouceSeeking Strategy: A Case Study on Chinalco and Rio Tinto. Asia-Pacific Journal of Accounting \& Economics, 17, 313-326.

Ye, G. (1992). Chinese Transnational Corporations. Transnational Corporations, 1(2), 125-133.

Zhan, J. X. (1995). Transnationalization and Outward Investment: The Case of Chinese Firms. Transnational Corporations, 4(3), 67-100.

Zhang, Y. (2009). Unravelling the Complex Motivation behind China's FDI. Tjalling C. Koopmans Research Institute Discussion Paper Series 09-02. 


\section{Appendix A: Host Countries and Home Countries List}

\section{Table A1: List of Host Countries}

\begin{tabular}{|c|c|c|c|c|c|}
\hline 1 & Afghanistan & 55 & Ghana & 109 & Papua New Guinea \\
\hline 2 & Albania & 56 & Greece & 110 & Paraguay \\
\hline 3 & Algeria & 57 & Grenada & 111 & Peru \\
\hline 4 & Angola & 58 & Guinea & 112 & Philippines \\
\hline 5 & Argentina & 59 & Guyana & 113 & Poland \\
\hline 6 & Australia & 60 & Honduras & 114 & Qatar \\
\hline 7 & Austria & 61 & Hungary & 115 & Romania \\
\hline 8 & Azerbaijan & 62 & India & 116 & Russia \\
\hline 9 & Bahamas & 63 & Indonesia & 117 & Rwanda \\
\hline 10 & Bahrain & 64 & Iran & 118 & Samoa \\
\hline 11 & Bangladesh & 65 & Iraq & 119 & Saudi Arabia \\
\hline 12 & Barbados & 66 & Ireland & 120 & Senegal \\
\hline 13 & Belarus & 67 & Israel & 121 & Seychelles \\
\hline 14 & Belgium & 68 & Italy & 122 & Sierra Leone \\
\hline 15 & Belize & 69 & Jamaica & 123 & Singapore \\
\hline 16 & Benin & 70 & Japan & 124 & Slovakia \\
\hline 17 & Bermuda & 71 & Jordan & 125 & South Africa \\
\hline 18 & Bolivia & 72 & Kazakhstan & 126 & South Korea \\
\hline 19 & Bosnia and Herzegovina & 73 & Kenya & 127 & Spain \\
\hline 20 & Botswana & 74 & Kuwait & 128 & Sri Lanka \\
\hline 21 & Brazil & 75 & Kyrgyzstan & 129 & St. Vincent \& Grenadines \\
\hline 22 & Brunei & 76 & Laos & 130 & Sudan \\
\hline 23 & Bulgaria & 77 & Latvia & 131 & Suriname \\
\hline 24 & Burundi & 78 & Lebanon & 132 & Sweden \\
\hline 25 & Cambodia & 79 & Lesotho & 133 & Switzerland \\
\hline 26 & Cameroon & 80 & Liberia & 134 & Syrian Arab Rep \\
\hline 27 & Canada & 81 & Libyan & 135 & Taiwan Province \\
\hline 28 & Cape Verde & 82 & Liechtenstein & 136 & Tajikistan \\
\hline 29 & Chad & 83 & Luxembourg & 137 & Tanzania \\
\hline 30 & Chile & 84 & Madagascar & 138 & Thailand \\
\hline 31 & Colombia & 85 & Malawi & 139 & Timor-Leste \\
\hline 32 & Congo & 86 & Malaysia & 140 & Togo \\
\hline 33 & Congo DR & 87 & Mali & 141 & Tunisia \\
\hline 34 & Cote d'lvoire & 88 & Malta & 142 & Turkey \\
\hline 35 & Croatia & 89 & Marshall & 143 & Turkmenistan \\
\hline 36 & Cuba & 90 & Mauritania & 144 & Uganda \\
\hline 37 & Cyprus & 91 & Mauritius & 145 & Ukraine \\
\hline 38 & Czech Republic & 92 & Mexico & 146 & United Arab Emirates \\
\hline 39 & Denmark & 93 & Mongolia & 147 & United Kingdom \\
\hline 40 & Djibouti & 94 & Morocco & 148 & United States \\
\hline 41 & Dominican Republic & 95 & Mozambique & 149 & Uruguay \\
\hline 42 & Ecuador & 96 & Myanmar & 150 & Uzbekistan \\
\hline 43 & Egypt & 97 & Namibia & 151 & Venezuela \\
\hline 44 & Equator Guinea & 98 & Nepal & 152 & Vietnam \\
\hline 45 & Eritrea & 99 & Netherlands & 153 & Yemen \\
\hline 46 & Ethiopia & 100 & New Zealand & 154 & Zambia \\
\hline 47 & Federal St. Micronesia & 101 & Niger & 155 & Zimbabwe \\
\hline 48 & Fiji & 102 & Nigeria & & \\
\hline 49 & Finland & 103 & North Korea & & \\
\hline 50 & France & 104 & Norway & & \\
\hline 51 & Gabon & 105 & Oman & & \\
\hline 52 & Gambia & 106 & Pakistan & & \\
\hline 53 & Georgia & 107 & Palau & & \\
\hline 54 & Germany & 108 & Panama & & \\
\hline
\end{tabular}


Table A2: List of Home Countries

\begin{aligned} & \hline 1 Australia \\ & 2 Austria \\ & 3 Belgium \\ & 4 Canada \\ & 5 Chile \\ & 6 Czech Republic \\ & 7 Denmark \\ & 8 Estonia \\ & 9 Finland \\ & 10 France \\ & 11 Germany \\ & 12 Greece \\ & 13 Hungary \\ & 14 Iceland \\ & 15 Ireland \\ & 16 Israel \\ & 17 Italy \\ & 18 Japan \\ & 19 Luxembourg \\ & 20 Netherlands \\ & 21 New Zealand \\ & 22 Norway \\ & 23 Poland \\ & 24 Portugal \\ & 25 Slovakia \\ & 26 Slovenia \\ & 27 South Korea \\ & 28 Spain \\ & 29 Sweden \\ & 30 Switzerland \\ & 31 Turkey \\ & 32 United Kingdom \\ & 33 United States \\ & \hline \\ & \\ & \hline\end{aligned}




\section{Appendix B: First Stage Estimations of TSLS}

Table B1: First Stage Estimation of TSLS for the Whole Sample

\begin{tabular}{|c|c|c|c|c|c|c|}
\hline \multirow{3}{*}{$\begin{array}{l}\text { Dependent: } \\
\text { lnCOFDIF }\end{array}$} & \multicolumn{2}{|c|}{ Model 1} & \multicolumn{2}{|c|}{ Model 2} & \multicolumn{2}{|c|}{ Model 3} \\
\hline & (1) & (2) & (3) & $(4)$ & (5) & $(6)$ \\
\hline & Coefficient & S.E. ${ }^{1}$ & Coefficient & S.E. ${ }^{1}$ & Coefficient & S.E. ${ }^{1}$ \\
\hline \multicolumn{7}{|l|}{ Host Country Characteristics } \\
\hline $\operatorname{lnRGDP}$ & $0.239 * * *$ & $(0.028)$ & $0.252 * * *$ & $(0.031)$ & $0.427 * * *$ & $(0.032)$ \\
\hline InRGDPPC & $0.175 * * *$ & $(0.035)$ & $0.155^{* * *} *$ & $(0.038)$ & 0.005 & (0.039) \\
\hline Technology & & & $0.805 * * *$ & $(0.276)$ & $1.173 * * *$ & $(0.277)$ \\
\hline Resources & & & & & $1.995 * * *$ & $(0.127)$ \\
\hline \multicolumn{7}{|l|}{ Home Country Characteristics } \\
\hline $\operatorname{lnRGDP}$ & 0.984 & $(2.580)$ & 3.380 & $(2.935)$ & 1.128 & $(3.039)$ \\
\hline $\operatorname{lnRGDPPC}$ & -0.463 & $(2.652)$ & -3.063 & $(3.023)$ & -1.778 & $(3.081)$ \\
\hline Technology & & & -0.549 & $(0.798)$ & -0.683 & $(0.801)$ \\
\hline Resources & & & & & -0.429 & $(1.900)$ \\
\hline \multicolumn{7}{|l|}{ Bilateral Characteristics } \\
\hline $\operatorname{lnExch}$ & -0.045 & (0.339) & -0.030 & $(0.407)$ & -0.159 & $(0.483)$ \\
\hline $\ln$ Area & $0.296 * * *$ & $(0.024)$ & $0.291 * * *$ & $(0.025)$ & $0.146 * * *$ & $(0.027)$ \\
\hline Colony & $0.243 * *$ & $(0.118)$ & $0.392 * * *$ & $(0.130)$ & $0.370 * * *$ & $(0.127)$ \\
\hline Comcol & $1.028 * *$ & $(0.471)$ & $0.871 *$ & $(0.511)$ & 0.574 & $(0.471)$ \\
\hline Comlang & $0.441 * * *$ & $(0.110)$ & $0.450 * * *$ & $(0.120)$ & $0.482 * * *$ & (0.119) \\
\hline Contig & $0.341 * *$ & $(0.149)$ & $0.337 * *$ & $(0.151)$ & $0.323 * *$ & $(0.146)$ \\
\hline $\operatorname{lnDist}$ & $0.490 * * *$ & $(0.035)$ & $0.509 * * *$ & $(0.035)$ & $0.455 * * *$ & $(0.035)$ \\
\hline Smctry & -0.088 & $(0.344)$ & -0.090 & $(0.343)$ & -0.178 & $(0.341)$ \\
\hline \multicolumn{7}{|l|}{ Excluded Instrument Variables } \\
\hline lnChinaDist & $-0.900 * * *$ & $(0.053)$ & $-0.872 * * *$ & $(0.059)$ & $-0.788 * * *$ & $(0.059)$ \\
\hline lnChinaExch & 0.084 & $(0.339)$ & 0.053 & $(0.408)$ & 0.172 & $(0.483)$ \\
\hline F test of excluded instruments & \multicolumn{2}{|c|}{143.470} & \multicolumn{2}{|c|}{110.350} & \multicolumn{2}{|c|}{89.390} \\
\hline p-value & \multicolumn{2}{|c|}{0.000} & \multicolumn{2}{|c|}{0.000} & \multicolumn{2}{|c|}{0.000} \\
\hline
\end{tabular}

Notes: ${ }^{1}$ Robust standard errors are in parentheses. Each regression includes a time trend as well as the home country dummy. Significant at $* 10 \%$, ** 5\% and *** $1 \%$. 